\title{
Mijloace pastorale, misionare, educationale și sociale pentru transmiterea dreptei credințe în rândul tinerilor și pentru integrarea acestora în viața comunitară a parohiei
}

\section{Miruna-Maria IFTENE}

\begin{abstract}
The life of the Church is founded on the parish. For this reason, the parish should be entrusted with the pastoral care of all age groups and social categories. However, special attention should be given to the young, because our society's future is rooted in them. Among all age groups, teenagers and young adults are most affected by the constant changes in contemporary culture, and they are responsible for the Church's continuity. The pastoral care of the youth comprises the Church's answer to the needs of young people and the transmission of young people's unique talents to the whole Christian community. Therefore, in order to cater for this age group, priests should work with teachers, psychologists and local authorities. In this essay, we will analyse various methods used in the pastoral care of young people.
\end{abstract}

Keywords: Community, catechesis, confessor, Eucharist, society.

Biserica urmează îndemnul Mântuitorului rostit către ucenici înainte de Înălțarea Sa la cer, ,propovăduiți Evanghelia la toată făptura“ (Marcu 16, 15), și adresează chemarea Sa mântuitoare 
tuturor oamenilor. O categorie aparte de persoane, cărora Biserica le acordă o atenție sporită prin misiunea pastoral-misionară a parohiei, o reprezintă cea a generației tinere. Tinerii reprezintă viitorul societății, iar trăsăturile lor morale și de caracter prefigurează viaţa religiosmorală a viitorilor adulți. Însă generaţia tânără nu trebuie limitată la prefigurarea viitorului, căci alături de generația adultă, aceasta reprezintă și prezentul, având nevoie să i se acorde o recunoaștere specială.

Însuşi Mântuitorul a acordat o atenţie deosebită generaţiei tinere, cele mai mari minuni ale lui Hristos, fiind săvârşite asupra tinerilor (învierea fiicei lui Iair - Marcu 5, 22-43; și cea a fiului văduvei din Nain - Luca 7, 12-15). „Această rechemare la viață, adresată tinerilor, din partea Fiului lui Dumnezeu întrupat, poate fi interpretată ca un simbol al invitaţiei permanente pe care Dumnezeu o lansează către cei tineri, pentru redescoperirea vieții întru, pentru și împreună cu El"’.

În cuvântul adresat tânărului din Nain, ,Tinere, ție îţi zic, scoală-te!" (Luca 7, 14), este prezentă o chemare și o poruncă pentru toți tinerii morți din punct de vedere duhovnicesc. Pe aceștia, Hristos Domnul îi cheamă să vină de la moarte la viață, la învierea vieții celei veșnice. Mântuitorul ,a venit în lume să-1 caute și să-1 mântuiască pe cel pierdut" (Luca 19, 10), altfel spus scopul suprem al Întrupării Sale şi, în final, al jertfei Sale pe cruce, a fost acela de a mântui lumea. El a socotit că răul cel mai mare de care trebuie să se teamă omul nu este moartea trupului sau moartea biologică, ci moartea sufletească. Deci, dacă cineva este viu cu trupul, dar trăiește în păcat, acela poate fi considerat ca fiind mort sufletește. Mântuitorul spune: „Nu vă temeți de cei ce ucid trupul, dar sufletul nu pot să-1 ucidă, ci mai degrabă temeți-vă de acela care poate ca și sufletul și trupul să le piardă în gheena" (Matei 10, 28).

${ }^{1}$ Ionuț Bursuc, Pastorația tinerilor ca misiune a Bisericii, http://www. doxologia.ro/actualitate/alte-articole/pastoratia-tinerilor-ca-misiune-bisericii (accesat la 1506 2015). 
Problema tinerilor este tratată în Noul Testament și de către Sfinţii Apostoli. În Epistolele Sfântului Apostol Pavel către Timotei este conturată poziţia tânărului în Biserică. Astfel, Apostolul Neamurilor, adresându-se ucenicului său, îl îndemna să își îndeplinească îndatoririle rezultate din misiunea sa cu dăruire şi grijă, astfel ca nimeni să nu-1 poată disprețui pentru vârsta sa tânără (I Timotei 4, 12). Totodată, Sf. Pavel arată importanța pe care o are vârsta tinereții în parcursul omului spre maturizarea duhovnicească.

Biserica creează în viața creștinului o stare de permanentă tranziție, în Sfânta Scriptură viața de pe pământ fiind comparată cu o călătorie spre viața cea veșnică. Deoarece la vârsta tinereții au loc la nivel psiho-fizic anumite procese care rezultă în omul adult, această vârstă deține un rol important în cadrul evoluției duhovnicești.

„Statutul de tranziție constituie, așadar, principala caracteristică a vârstei tinere, el fiind asociat în mod curent cu nevoia de schimbare manifestată cu precădere la tineri. Acest fapt este cu atât mai evident în cazul tinerilor români, care, la acest început de mileniu, sunt puși în situația de a experimenta o dublă schimbare sau, actualizând terminologia, o „dublă tranziție”. Tranziţia experimentată de către tinerii români este dublă, întrucât, pe de o parte, ea este implicată de vârsta acestora, iar pe de altă parte, societatea în care acești tineri trăiesc se află într-un lung şi dificil proces de tranziție, fenomen ce determină o serie întreagă de consecințe la nivelul vieții individuale și sociale. Problemele cu care se confruntă tinerii români astăzi sunt, pe de o parte, asemănătoare celor care îi privesc pe tinerii din țările occidentului european (droguri, alcool, sexualitate, SIDA, satanism, suicid), dar au din nefericire și suficiente note distinctive, determinate de climatul economic instabil, nesiguranța și lipsa de perspectivă, (şomaj, emigrare, exodul tinerilor bine pregătiţi profesional etc.)"2.

\footnotetext{
${ }^{2}$ Pr. Ionel Constantin-Maloș, Pastorația, între întrebările tinerilor și răspunsul Bisericii, http://www.crainou.ro/2008/09/11/pastoratia-intre-intrebarile-tinerilor -si-raspunsul-bisericii/ (accesat la 1006 2015).
} 
Parohia trebuie să devină locul în care tinerii își descoperă adevărata lor identitate, de făpturi create după chipul lui Dumnezeu, cât și scopul lumii acesteia - dobândirea vieții veșnice. În cadrul parohiei, misiunea preotului este una dublă: pe de o parte, acesta trebuie să-i atragă pe tineri către Biserică, iar de pe cealaltă parte, preotul trebuie să ducă Biserica la tineri, în sensul de a le dezvolta un spirit comunitar. Preotul trebuie să încurajeze întreaga comunitate parohială să se aplece asupra tinerilor și să contribuie la evoluția lor duhovnicească.

„Bazată pe comunitatea euharistică locală, parohia oferă cel mai potrivit mijloc de creștere duhovnicească a membrilor ei de toate vârstele și categoriile sociale. Tânărul, ca și cel în vârstă, omul simplu, ca şi intelectualul, cel nevoiaş ca și cel înstărit pot găsi în comunitatea parohială din care fac parte ambianța necesară unei viețuiri creștine autentice. Toate celelalte forme ale misiunii Bisericii Ortodoxe prezente în afara parohiei: în școală, armată, spital, penitenciar, orfelinat sau învățământul teologic au importanța lor în măsura în care persoana cuprinsă în atare formă de misiune este orientată spre integrarea plenară în comunitatea euharistică locală - parohia"3.

Mijloacele de pastorație pentru tineri trebuie să includă și să se bazeze pe activități cu caracter duhovnicesc: organizarea de întâlniri săptămânale cu tinerii parohiei, iniţierea de pelerinaje, organizarea de cateheze cu teme specifice vârstei, favorizarea alegerii unor tineri în structura consiliilor și comitetelor parohiale, implicarea în predarea religiei în școală, organizarea unor coruri parohiale de tineri etc., însă acestea trebuie completate şi de activități cultural-sociale, care să-i încurajeze în petrecerea cu folos și în duh creștin a timpului liber: acordarea de ajutoare unor tineri cu probleme sau cu rezultate excepționale la învățătură, dar și ajutorarea persoanelor nevoiașe prin

\footnotetext{
${ }^{3}$ Î.P.S Teofan Savu, Parohia - element esențial al pastorației tinerilor, http://www.doxologia.ro/cuvantul-ierarhului/parohia-element-esential-alpastoratiei-tinerilor (accesat la 1506 2015).
} 
participarea tinerilor, vizitarea unor obiective culturale (muzee, case memoriale, monumente etc.), audierea de concerte de muzică clasică, vizionarea unor piese de teatru cu caracter moralizator, practicarea diferitelor sporturi, inițierea unor cercuri de lectură etc. Tinerii trebuie încurajați să-şi schimbe întregul mod de viață, să propovăduiască în întreaga societate învățăturile Bisericii prin vorbă, dar mai ales prin faptă, atrăgând astfel către Biserică alți tineri. Apartenența tinerilor la parohie trebuie dublată și de conștiința națională, prin aprofundarea istoriei României, prin dezvoltarea spiritului civic şi patriotic, recunoașterea meritelor eroilor neamului și cinstirea acestora.

Având în vedere gradul ridicat de folosire a mijloacelor de comunicare virtuală în rândul tinerilor, cât și faptul că internetul a devenit „un instrument revoluționar pentru răspândirea învățăturilor moral-religioasă" ${ }^{\prime}$, Biserica trebuie să folosească și acest mod pentru a facilita atragerea și comunicarea cu tinerii, prezența Bisericii în spațiul virtual nefiind altceva decât împlinirea poruncii de a propovădui adevărul mântuirii în toată lumea.

Astfel, site-ul parohiei trebuie să dețină o rubrică dedicată tinerilor, care să cuprindă atât articole care prezintă răspunsul Bisericii la problemele și preocupările acestei vârste, cât și articole în care se explică diferite învățături de credință pe înțelesul lor, ambele tipuri de articole putând fi însoțite de conținut foto, video sau audio. De asemenea, site-ul parohiei poate deține un link către blogul tinerilor, care reprezintă o altă modalitate de pastorație a acestora la nivel virtual: „Blogul tinerilor din parohie este un proiect cu rol pastoralmisionar bidirecțional. Pe de o parte, îi vizează pe tinerii integrați deja în comunitatea parohială, iar, pe de altă parte, îi privește pe tinerii a căror legătură cu comunitatea parohială este sporadică sau chiar absentă, dar care sunt foarte bine integrați în comunitatea virtuală a

\footnotetext{
${ }^{4}$ Heidi Campbell, Exploring religious community online, New York, Peter Lang Publishing, 2010, p. 61.
} 
bloggerilor"s.

Tinerii sunt prezenți într-un număr foarte mare și pe rețele de socializare, iar Biserica trebuie să fie și ea prezentă cu aceeași misiune ca și în societate, și în spațiul virtual. Astfel, în cadrul rețelelor de socializare se pot crea grupuri speciale pentru tinerii parohiei, pentru a se facilita comunicarea cu aceștia și pentru a se anunța diferite activităţi ce vor fi desfăşurate.

$\mathrm{O}$ altă direcție în misiunea pastorației tinerilor o reprezintă relația acestora cu duhovnicul. Într-un articol dedicat tinerilor, în care subliniază importanța legăturii lor cu Biserica, prin duhovnici, Prea Fericitul Părinte Patriarh Daniel amintește că „duhovnicii sunt cei care manifestă o familiaritate cu Dumnezeu creatoare de pace, putere, viață plină de har. Este important pentru tineri să păstreze legătura cu duhovnicul cel mai apropiat; doar astfel pot redescoperi dimensiunea spirituală a vieții lor și-L pot regăsi pe Hristos în inimile lor, astfel putând trăi o viaţă autentic creștină. Pe de altă parte, ei trebuie să consulte și duhovnici experimentați, gata să-și ofere sfatul și rugăciunea lor pentru permanenta înviere a sufletelor tinere"\%.

Duhovnicul trebuie să fie părintele tuturor tinerilor din parohie, atât al băieților, cât și al fetelor. Ceea ce tânărul sau tânăra nu îndrăznește să mărturisească părinților trebuie să aibă curaj să-i spună părintelui duhovnicesc. De asemenea, prezbitera poate să-și asume și ea un rol important în abordarea problemelor fetelor care au o tematică și o psihologie specifică. Preotul trebuie să identifice persoanele laice care-i pot ajuta pe tineri în funcție de problemele acestora, apelând când este nevoie la ajutorul unui psiholog și încheind parteneriate cu instituțiile de învățământ din raza parohiei, și nu în ultimul rând să apeleze la familia tânărului.

${ }^{5}$ Gheorghe Cristian-Popa, Preotul misionar în areopagul mediatic. Mijloace moderne de comunicare în pastorația ortodoxă, București, Editura Cuvântul Vieții a Mitropoliei Munteniei și Dobrogei, 2013, p. 86.

${ }^{6}$ Î.P.S Daniel Ciobotea, (actualul P.F. Daniel), Tinerii, viitorul spiritual al României, în „Candela Moldovei”, 3-4, 1999, p. 9. 
„Responsabilitatea educativă a păstorului pretinde, pentru a fi mai eficace, ca acțiunea lui să fie conjugată cu aceea a familiei și a altor prezențe educative care acționează în teritoriu. Această coordonare educativă este necesară pentru a se putea realiza ceea se se numește un sistem educativ unitar. De fapt, acest sistem nu poate fi gândit fără o puternică prezență educativă a diferite instituții”’’

Prin urmare, pastorația tinerilor poate urma două mari direcții: integrarea tinerilor în cadrul parohiei prin programe pastoralmisionare și descoperirea de către tineri a relației cu duhovnicul, atât prin Taina Sfintei Spovedanii, cât și prin discuții, întruniri etc.

De remarcat este faptul că pastorația tinerilor nu reprezintă doar o ramură care se adaugă misiunii Bisericii, ci trebuie să devină parte integrantă a acesteia, fiind o componentă de bază a spiritualității creștine, care ne arată că nivelul nostru duhovnicesc depinde de maniera în care ne comportăm față de nevoile semenilor noștri. Astfel, datorită faptului că misiunea pastorală reprezintă o dimensiune a spiritualității, pastorația tinerilor nu poate reprezenta un capitol separat al lucrării pastorale a Bisericii, realizată la îndemnul Mântuitorului. Tinerii, ca membri ai trupului lui Hristos, prezintă niște nevoi speciale, precum cea de a contracta relaţii cu alte persoane, de diferite vârste.

Tinerii români trăiesc o viață prinsă între mai multe chemări. Ei aud şi ascultă, mai mult ca niciodată, chemarea lumii secularizate, care consideră că Biserica trebuie să-şi manifeste activitatea şi misiunea numai în viața privată, nu și în societate. Acest mod de viaţă al lumii secularizate permite apariția unei libertăți aparent totale, care prin îmbrățișarea tentațiilor ei, înlănțuiește tânărul într-o sclavie din care nu mai găsește calea de ieșire. Aici intervine misiunea Bisericii, a clericilor și a laicilor deopotrivă, de a-i menține pe tineri pe drumul adevăratei libertăţi în Hristos, căci „,o autentică acțiune pastorală de

${ }^{7}$ Arhim. Teofil Tia, Elemente de pastorală misionară pentru o societate postideologică, Alba-Iulia, Editura Reîntregirea, 2003, p. 375-376. 
care urmează să beneficieze tânărul îl conduce la primirea cu smerenie a harului divin, înţelegând că nu atât de mult el este acela care trebuie să lucreze, cât mai mult Creatorul trebuie lăsat să realizeze în el fapta Sa"».

Prin urmare, pastorația tinerilor trebuie să identifice atât mijloacele potrivite de comunicare cu tinerii, cât și metodele optime de prezentare a existenței și lucrării lui Dumnezeu în lume și în viaţa lor. Deși Evanghelia este una singură, din motive pastoral-misionare, încă din primele secole creștine s-a putut constata o diferențiere a modalităţii prezentării mesajului Evanghelic în funcție de persoanele cărora i se adresează.

„În prezent, configurarea unei strategii misionare diferențiate după astfel de criterii, reprezintă o misiune și o sarcină prioritară atât la nivelul reflecției teologice, cât mai ales în planul concret al practicii pastorale cotidiene. Acordând atenție tineretului, practica pastorală se înnoiește pe sine, astfel încât pastorația tinerilor devine dintr-o sarcină a misiunii Bisericii, o șansă a propriei sale întineriri și revigorări spirituale"”.

\section{Bibliografie}

1. Baloyannis, Stavros I., Psihologie pastorală, Iași, Doxologia, 2015.

2. Calciu, Pr. Gheorghe, 7 cuvinte către tineri, București, Editura Anastasia, 1996.

3. Campbell, Heidi, Exploring religious community online, New York, Peter Lang Publishing, 2010,

\footnotetext{
${ }^{8}$ Pr. Ilie Moldovan, Familia astăzi, probleme pastorale și sociale. Pastorația copiilor, a tinerilor și a bătrânilor în vol. Bucuria nunții binecuvântate. Cateheze pentru familia creștină, București, Editura „Cuvântul Vieții” a Mitropoliei Munteniei și Dobrogei, 2011, p. 164.

${ }^{9}$ Ionuț Bursuc, Pastorația tinerilor ca misiune a Bisericii, http://www. doxologia.ro/actualitate/alte-articole/pastoratia-tinerilor-ca-misiune-bisericii (accesat la 1506 2015).
} 
4. Ciobotea, Î.P.S Daniel, (actualul P.F. Daniel), Tinerii, viitorul spiritual al României, în „Candela Moldovei”, 3-4, 1999.

5. Dumitru, Laurențiu, Tinerii pe calea întrebărilor, Galați, Editura Egumenița, 2004.

6. Dumitru, Laurențiu, Hristos și tinerii, Galați, Editura Egumenița, 2005.

7. Himcinshi, Pr. Mihai, Biserica în societate. Aspecte misionare ale Bisericii în societatea actuală, Alba-Iulia, Editura Reîntregirea, 2006.

8. Ilucă, Monahul Paulin, Manifest pentru păstrarea tinereții, Galați, Editura Egumenița, 2010.

9. Ilucă, Monahul Paulin, Rugăciuni pentru tineri, Galați, Editura Egumenița, 2008.

10. Kokulis, Ioannis V., Imbisericirea elevilor pentru o educație religioasă liturgică, trad. P.S. Mihail Filimon, Sibiu, Editura Deisis, 2012;

11. Marler, Monahul John, Wermuth, Monahul Andrew, Tinerii vremurilor de pe urmă. Ultima și adevărata răzvrătire, trad. Felix Trușcă, București, Editura Sophia, 2002.

12. Metallinos, Gheorghios D., Parohia - Hristos în mijlocul nostru, trad. Pr. Prof. Ioan I. Ică, Sibiu, Editura Deisis, 2014;

13. Moldovan, Pr. Ilie, Familia astăzi, probleme pastorale și sociale. Pastorația copiilor, a tinerilor și a bătrânilor în vol. Bucuria nunții binecuvântate. Cateheze pentru famlia creștină, București, Editura Cuvântul Vieții a Mitropoliei Munteniei și Dobrogei, 2011.

14. Neagu, Andreea-Raluca, ,Mass-media și spiritualitatea tinerilor de azi” în „Lumina de Duminică”, 5 februarie 2012.

15. Popa, Gheorghe-Cristian, Preotul misionar în areopagul mediatic. Mijloace moderne de comunicare in pastorația ortodoxă, București, Editura Cuvântul Vieții a Mitropoliei Munteniei și Dobrogei, 2013.

16. Prescure, Arhim. Vasile; Stan, Pr. Nicolae Răzvan (coord.), Tineretul și crestinismul: repere duhovnicești pentru tinerii vremurilor noastre, Craiova, Editura Mitropolia Olteniei, 2008.

17. Tia, Arhim. Teofil, Elemente de pastorală misionară pentru o societate post-ideologică, Alba-Iulia, Editura Reîntregirea, 2003. 
18. Trif, Pr. Ilie (coord.), Paradoxul creștin și cartea tinereții, AlbaIulia, Editura Reîntregirea, 2008.

\section{Surse web:}

1. Bursuc, Ionut, Pastorația tinerilor ca misiune a Bisericii,

2. http://www.doxologia.ro/actualitate/alte-articole/pastoratiatinerilor-ca-misiune-bisericii (accesat la 1506 2015).

3. Maloș, Pr. Ionel Constantin, Pastorația, între întrebările tinerilor și răspunsul Bisericii, http://www.crainou.ro/2008/09/11/ pastoratia-intre-intrebarile-tinerilor-si-raspunsul-bisericii/ (accesat la 1006 2015).

4. Savu, Î.P.S Teofan, Parohia - element esențial al pastorației tinerilor, http://www.doxologia.ro/cuvantul-ierarhului/parohiaelement-esential-al-pastoratiei-tinerilor (accesat la 1506 2015). 